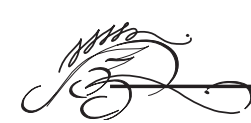

UDC $37.014 / .09-025.27$

DOI: $10.30837 /$ nc.2020.2.25

\title{
Cluster governance of School-university clusters
}

\author{
Sven-Olof Yrjö Collin \\ Professor of Corporate Governance, Free University of Scania, \\ Honorary Professor of Kharkiv University of Humanities \\ "People's Ukrainian Academy"
}

\section{Introduction}

Clusters can be defined by being a non-formal organization consisting of a collection of independent organizations, joined together by a common interest, sharing and transferring resources, including knowledge, with a microculture, i.e., a fairly homogenous value system (Lazerson, 1993), with a governance structure, where "Governance promotes a cluster's evolutionary process since it leads to the achievement of better performance by the organizations individually and by the cluster as a whole." (Cassanego Jn, Boaventura, Azevedo \& Telles, 2019:987).

The definition stresses the autonomy of the member organizations; thus a cluster is not a hierarchical system of organisations, but a network of organizations. Since no member of the cluster is sub-ordinate to another member, they are together in the cluster because of a common interest. No member organization is but a mean for the cluster, since it is the cluster that is a mean for each member. This makes clusters naturally flat organizations, even if there could be hierarchical features in parts of the cluster. The member organizations are in the cluster in order to profit from exchanges or sharing of resources, for example being a quasi-internal labour market, where individuals are transferred between the member organizations. The cluster could produce a brand that are shared by all member organizations. There could be financing in common or the cluster could constitute a quasi-internal capital market. Most often identified is the sharing of and the creation of knowledge, which could foster innovation in the member organisations or on the cluster level. The governance of a cluster tends to be ambiguous since a clusters competitive advantage compared to an integrated organisation is its dynamic structure. Overall, it tends therefore to be a network, without a centre, where coordination of action and exchanges are conducted in a flat organization.

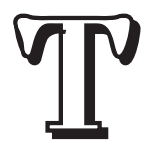
he school-university cluster could at first sight be expected to have a hierarchical character since the educational system is hierarchical, with schools being placed up-streams in the educational system, supplying the universities with students. However, the educational system is also a professional system, containing elements of academic freedom, which create an authoritarian culture, where formal position is less important compared to the authorian capacity of recognised professionals. This character will be expected to influence several aspects of the school-university cluster, for example its governance.

Governance of a cluster with the authoritarian form

A cluster can be organized based on geographical proximity, such as Silicon Valley, which was the starting point of

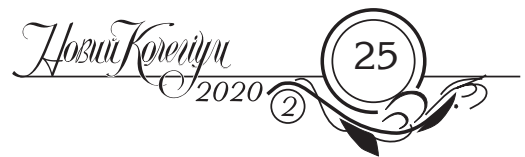


cluster literature, by Marshall's (1920) notion of industrial districts. But geographical proximity is not a prerequisite today, with the advanced information technology available (Bahlmann \& Huysman, 2008). A cluster can be organised around a common interest, where exchanges are hard to predict, making the cluster a network of established, but more important, of potential linkages. The strength of the cluster is not so much as what it is doing, but what it can do, i.e., its promises of development. Thus, membership of a cluster becomes important since membership can secure access to the resources of the cluster and its potentiality.

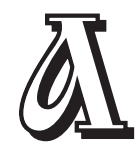
cluster contains cluster members with actual and potential relationships. These relationships will be governed. Established research (Bell, Tracey \& Heide, 2009) points out two idealtypical modes of governance of clusters, hierarchical and relational. Hierarchical is a centralized mode of governance, where parties give up part of their autonomy to the centre. Relational is a decentralized mode where the parties are in full control of their autonomy and follow shared norms.

These two categories have been found to be practical in understanding clusters containing profit-seeking private firms. But when we consider a schooluniversity cluster, we have to realize that it contains a distinct professional cadre, with some specificities in their cultures. With this notion, we can add a third cluster governance form, the authoritarian form. It is a decentralized form, thus keeping the autonomy of the organizations, but with centres where authorities are located.

This third form of cluster governance is made possible through the macroculture (Bell, Tracey \& Heide, 2009) of the educational industry. In the old days it was given a label with bad connotations, professor empire. But professor empire is a hierarchal form, where professors has power due to their formal position of being professor. In an authoritarian governance form the person does not have the authority due to position, but due to individuals of the cluster admitting power through acceptance and respect for the individual's competence. It could be close to the Weberian idealtype of charismatic leadership, but in a cluster, there is not a single leadership but several, i.e., there are many authorities. A more precise term could be Primus inter pares, in a group of equals, one is the foremost. This gives it a decentralized character but with many centres.

Practically this means that while entrance of an organization to a cluster could be decided by the head of a school or university, the relationships by individuals that are created and the potentiality of relationships should be left for actors of the cluster. It could be anyone from any member organization, but maybe especially made by the authorities of the different organizations. By this, the cluster keeps its flat and dynamic character but can have hierarchal character of coordination, based on authority and not formal power. This is a possibility of dynamics that is created by the microculture of professionalism.

Organizationally this implies that the principals of the cluster are the organizational members of the cluster, while the agents are the actors within the cluster, that trough their actions create and sustain the cluster. Contrary to agency theory, there is no delegation from the principal to the agent, because delegation would imply hierarchy. Instead, the principal is the one that create the arena and support the arena of actual and potential interaction. The principal is the servant of the agents, those that act on the arena, and thereby create the performance of the cluster. This character put a lot of demands on the rectors of schools and universities, that could be accustomed of being the boss of the organization, that now have to turn into a servant of the cluster organization.

Interaction creates the value of the cluster 
A cluster gets it creative capacity from the interaction between individuals. It could be tempting to believe that interaction will come through meetings. It is probably the other way around, that through interaction, individuals belonging to member organizations of the cluster will meet. The meeting is the point where the knowledge transfer or creation will happen, be it planned or spontaneous. A dynamic feature of the cluster interaction is probably the spontaneous element in the interaction, where knowledge will be transferred and innovation will be created. One of the most important products of the cluster can therefore be regarded to be an externality (Bahlmann \& Huysman, 2008), i.e., an outcome not planned for and not able to plan.

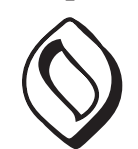
ne could believe that if the most efficient outcome are created through spontaneity, and that happens in interaction, then creating meetings where this interaction can happen, would be important in clusters. Since we do not know so much about cluster management, we can not tell for sure, but there are reasons to not believe that meetings with intention to scan interest and look for spontaneous opportunities are the best method.

Mphahlele L. K. (2012) reported about experience from school clusters in South Africa, where participants were rather negative to the cluster organisation, where meetings included too many disinterested members and stressed conformability. This indicate that the cluster meetings were organized as a formality where meetings were expected to create interactions which would create the efficient outcome. One could also expect that 'meetings for the sake of meetings' attract individuals that are prone to organize and attend meetings, for the sake of meetings. In this way, the cluster will become a meeting cluster, where resources are not created but consumed in numerous meetings.

One could claim that the reverse order would be more efficient, that the need of interaction create meetings. Then there will be interested individuals in the meeting, with an aim to discuss concrete problems. In this operational interaction knowledge is exposed and transferred, and as a byproduct, as an externality, new ideas can be created.

Thus, meetings for the sake of meetings run the risk of being staffed with disinterested meeting individuals, that seek confirmation of cluster participation, instead of a working team, solving assignments and through that process create interaction that can create new ideas.

Vertical system stimulates cooperation in a cluster

The clusters could idealtypical be either horizontal, i.e., members are in similar industries, even with competing products or services, or vertical, where members are part of each other's value chain. For a university, it could be cluster integration backwards, to lower levels school, and/ or integration forward, to organizations hiring the students and eventually the teachers of the cluster. Vertical clusters are those including organizations that do not compete at all in their output, but would compete in input factors, while horizontal clusters have organizations also competing on output, i.e, their service or products. Cooperation will be different depending if it is a vertical or horizontal cluster. There are examples of clusters that have extensive cooperation between competitors, for example the "Third Italy" district (Bahlmann \& Huysman, 2008). In school-university clusters the vertical dimensions will probably be dominating.

The vertical character of the cluster will foster interaction. Teachers can be circulated in the cluster, on the least ambitious level, auscultating other lectures, or on a more ambitious level, participating or even doing the lecturing, and participating, at least as observers at the end of the value chain, the final employers of the students. One would expect that in a good vertical educational system, the content and value of lifetime learning could be fostered. Another cornerstone in the educational

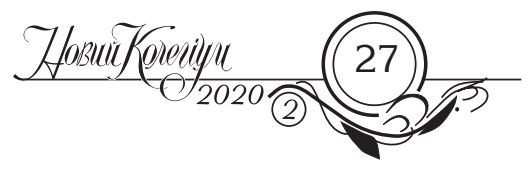


system, the importance of progression, would also become more exposed.

The vertical character of the cluster will also promote an early warning system. Advanced organisations try to create early warning systems, especially concerning important input resources, but also concerning output markets. The school-university clusters, especially those with distinct vertical orientation, have opportunity of an early warning system. Schools can change or experience changes among pupils that can be expected to be carried through the system. In Sweden, many universities have been surprised by the lower level of knowledge in certain subjects. Had they had contacts with up-stream gymnasiums in a cluster, this development could have been transmitted to the universities, making them capable to plan and adjust for the change. The information can go the other way, from the organizations employing students signalling their needs, that then can be transmitted in the cluster.

\section{Expanding the cluster}

How do a cluster know where there are potential members of the cluster? One solution is to create a specific responsibility for one or several employees of cluster organizations to find new members. This is, however, a solution of formalization that probably demands a specific organization, thus creating tendencies of centralizing cluster responsibilities, and thereby tendency of a hierarchical model of governance. An alternative approach is to let all employees of the cluster organisations have the responsibility of scanning the world for new members. If an employee goes to a conference or visit a school, of some reasons, that employee should have and should feel the responsibility to look for new members. Member attraction should be part of every employee responsibility. That will make the scanning for new members more wide, but at the same time, it will promote the common culture of the cluster, thus promoting a relational governance culture.
The new members can be expected to be among young or old organisations. There is probably an organizational life cycle fostering cluster membership. Young organizations have normally a weak resource base, making them prone to bootstrapping methods (Skoglund, 2019), of which one is cluster membership. When growing in size, they tend to have more of internal resources and to formalize, with less need of a cluster membership. At the top, as resourceful organizations, they are formalized and have maybe become a little less innovative, dynamic and flexible. Then they need the flexibility push from the cluster, and innovation ideas floating in the cluster. Thus, young organization needs the cluster for resources, and the old need the cluster for innovation.

\section{Conclusion}

School-university clusters do not appear to be common but would have good opportunities to be a dynamic agent in the educational system. Due to a common value system, a governance system in between the hierarchal and the relational system, the authoritarian mode of governance can be used. Stressing operational interaction will probably increase the efficiency of the cluster. A cluster with vertical orientation will create stronger incentives for interaction. Finally, it was claimed that expansion of the cluster should be every organizational members responsibility. By this, there is an emphasis on the relational, dynamic character of a cluster.

\section{References}

1. Bahlmann, M. D., Huysman, M. H. (2008). The emergence of a knowledgebased view of cluster and its implications for cluster governance / / The Information Society, 24:304-318.

2. Bell, S. J., Tracey, P. and Heide, J. B. (2009). The organization of regional clusters // Academy of Management review, 34(4):623-642. 
3. Cassanego Jn, P. V., Boaventura, J. M. G., Azevedo, A. C. and Telles, R. (2019). Governance in business clusters: proposal for an application of an analytical model // Entrepreneurship \& Regional Development, 31 (9-10): 984-1010.

4. Etzioni, A. (1964). Administrative and professional authority // A. Etzioni, Modern Organizations, Englewood Cliffs, NJ : Prentince-Hall.

5. Factory or putting-out? Knitting networks in Modena // The embedded firm. On the socio-economics of industrial networks, ed. Grabher G., 1993, pp. 203-
226. London: Routledge.

6. Marshall, A. (1920). Principles of economics. London: MacMillan.

7. Mphahlele L. K. (2012) School cluster system: A qualitative study on innovative networks for teacher development // Procedia — Social and Behavioral Sciences, 47:340-343.

8. Skoglund W. (2019) Microbreweries and finance in the rural north of Sweden a case study of funding and bootstrapping in the craft beer sector // Research in Hospitality Management, 9(1):43-48.

15.02 .2020

Коллін Свен-Олофб

\section{УПРАВЛІННЯ УНІВЕРСИТЕТСЬКИМИ КЛАСТЕРАМИ}

\section{Анотація}

Освітніх кластерів, які поєднують університет та школу, не так вже й багато, так само як і досліджень про них. Але вони можуть бути впливовим чинником розвитку системи освіти, оскільки мають спільну систему цінностей, що дозволяє використовувати авторитарний підхід до управління та вертикальну систему взаємодії.

Ключові слова: авторитарне управління, взаємодія, система цінностей.

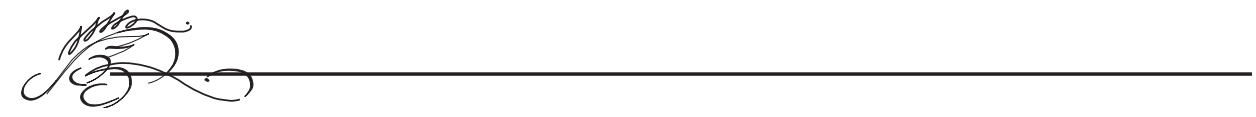

\section{Исследоватепьская раБоТа ммадШиХ Школьннков как экемент механнзма взанмодействня внгтрн овразоватепьного кмастера}

Зол Шилкунова, кандидат педагогических наук, учитель-методист, Специализированная экономико-правовая школа, Харьковский гуманитарный университет «Народная украинская академия»

"Собраться вместе есть начало. Держаться вместе есть прогресс.

Работать вместе есть успех».

(Генри Форд)

Начавшаяся в Украине реформа образования является ответом на внешние и внутренние вызовы. Построение Новой украинской школы базируется на четком понимании проблемных зон современной школы, игнорирование которых не позво-

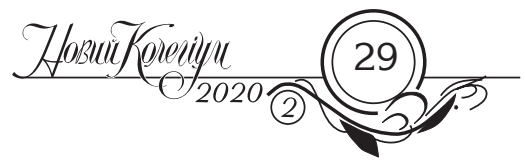

